\title{
ОРГАНІЗАЦІЯ РОБОТИ ТА КОНЦЕПТУАЛЬНА МОДЕЛЬ ДОСЛІДЖЕННЯ ПСИХОЛОГІЧНИХ КОМПОНЕНТІВ ІМІДЖУ УНIВЕРСИТЕТУ
}

\section{Чернега Наталія Сергївна}

Аспірант кафедри психології Київського начіонального торговельно-економічного університету, м. Київ (Украӥна)

\begin{abstract}
Анотація. У статті «Організація роботи та концеептуальна модель дослідження психологічних компонентів іміджу університету» представлено аналіз наукових підходів, організачію роботи, визначено психодіагностичний інструментарій дослідження компонентів, щзо впливають на формування іміджу вищзого навчального закладу, розкрито зміст конщептуальної моделі, обтрунтовано методи дослідження. При цьому використано загальнонаукові принциии дослідження: принциип системного підходу розуміння особистості, принц̧ип детермінізму та розвитку, єдності свідомості та діяльності особистості, методологічні принципи організації дослідження.

Розроблено і розкрито зміст конщептуальної моделі дослідження компонентів іміджу вищого навчального закладу з включенням таких блоків, як : теоретико-методологічне підгрунтя дослідження іміджу, етапи дослідження, психодіагностичний блок методик та компоненти формування іміджу вищцого навчального закладу.
\end{abstract}

Ключові слова: кониептуальна модель, дослідження, психодіагностика, імідж, вищий навчальний заклад.

Постановка проблеми. Дослідження проблем іміджу організацій набувають останнім часом все більшої практичної та теоретичної значимості. Це пов'язано з тими змінами та нововведеннями, які відбуваються в економічній, політичній, освітній та інших сферах життя нашого суспільства.

Перехід України до ринкових умов господарювання викликає в населення потребу отримання вищої освіти, що зумовлює конку- ренцію між вищими навчальними закладами у боротьбі за якість навчання та кількість студентів, що зумовлює прискіпливу увагу адміністрації до іміджу вищого навчального закладу.

Проблеми, пов'язані з психологічною діагностикою іміджу вищої освітньої організації, в сучасній українській та закордонній науковій літературі розглядаються недостатньо повно, тому науковим практичним завданням нашого дослідження є обгрунтування методів 
та розроблення концептуальної моделі дослідження формування іміджу університету.

За результатами аналізу наукових джерел теоретико-методологічних підходів дослідження психологічних детермінант формування іміджу освітніх установ 3'ясовано, що значна кількість визначених компонентів свідчать про можливість та необхідність 3'ясування внутрішніх та зовнішніх чинників, що зумовлюють формування іміджу, а з іншої сторони - вказують на необхідність комплексного підходу у дослідженні щодо психодіагностики детермінант іміджу вищого навчального закладу [ 4, 6, 7].

В загальному визначені проблема, що досліджується пов'язана 3 важливим науково-практичним напрямом, який зазначено в Національній стратегії розвитку освіти в Україні на 2012-2021 рр. в якій стверджується, що освіта розглядається як стратегічний ресурс соціально-економічного, культурного та духовного розвитку суспільства, поліпшення добробуту людей, забезпечення національних інтересів, зміцнення міжнародного авторитету та іміджу нашої держави, створення умов для самореалізації кожної особистості [16].

Аналіз останніх досліджень. Дослідження іміджу в зарубіжній літературі більше стосується загальних корпоративних аспектів, які можна перенести й на імідж навчальних закладів (Г. Даулінг, Л. Якока, Д. Мерсер). Вивчення аспектів іміджу вищих навчальних закладів досить широко представлені у працях іноземних фахівців Е. Беккер, Т. Бурделова, А. Юданова та інших науковців [2].

Разом 3 тим, вітчизняні дослідження останнього часу значно розширили наукове уявлення про принципи діагностики формування іміджу освітньої установи (Л. Карамушка); створення іміджу вищого навчального закладу (Ю. Карпенко, В. Кубко); військовослужбовця (М. Корольчук, В. Корольчук, С. Миронець, В. Осьодло); держслужбовця (В. Дашевський) $[4,5,6,7,9]$.

Отже, від загальних проблем дослідження, в яких започатковано вирішення даної проблеми, ми переходимо до з'ясування завдань щодо організації, обгрунтування психодіагностичного інструментарію та розробки концептуальної моделі дослідження.

Мета статті здійснити аналіз наукових підходів психодіагностичного інструментарію дослідження компонентів іміджу університету, а також розробити і розкрити зміст концептуальної моделі дослідження.

Виклад основного матеріалу. Теоретико-методологічне підгрунтя дослідження психологічних компонентів іміджу вищого навчального закладу складають фундаментальні принципи психологічної науки: принцип детермінізму та розвитку, єдності свідомості та діяльності (Б. Ананьєв, Л. Виготський, С. Рубінштейн); принцип системного підходу розуміння особистості (Б. Ананьєв, Б. Ломов, С. Максименко, К. Платонов); принцип психологічної теорії діяльності (Г. Балл, О. Леонтьєв, Н. Караму- 
шка, С. Максименко); методологічні принципи організації дослідження (Б. Ломов, Н. Карамушка, М. Корольчук) [4, 5, 6, 7, 15].

Якість проведення психодіагностичного дослідження значною мірою залежить від дотримання необхідного алгоритму. Окрім таких аксіоматичних правил психодіагностики, як поєднання у дослідженні раціонального і чуттєвого, використання наукового методу, що забезпечує об'єктивність даних, важливого значення набувають й інші вимоги, зокрема порядок проведення дослідження, врахування різноманітних змінних, які впливають на об'єктивність діагностичного процесу $[4,7]$.

Так, починаючи дослідження, має бути чітке уявлення проблеми й основного методичного задуму експерименту, знання процедури, змісту методик, мають бути заготовлені необхідні матеріали. При підготовці до дослідження необхідно проаналізувати змінні, пов'язані 3 процедурою експерименту, що впливають чи можуть вплинути на якість діагностичної інформації $[1,7,15]$.

Проведення вимірів у строго стандартизованих і контрольованих умовах дозволяє одержати найбільш точні результати експерименту і надійну інтерпретацію тестів. Поза стандартизацією якість інтерпретації психодіагностичних даних може погіршуватися в залежності від того, наскільки суттєві відхилення в процесі дослідження від заданих. Щоб уникнути перекручування досліджуваних явищ, процес дослідження повинен максима- льно близько відтворити ті умови, при яких розроблені норми й отримані дані про надійність і валідність методики.

Нині широко використовується алгоритм проведення дослідження запропонований Л. Бурлачуком [1]:

I. Пояснення обстежуваним мети проведення дослідження.

II. Гарантування збереження таємниці проведення дослідження.

III. Відповідно до вимог та рекомендацій проведення тренування.

IV. Заповнення (якщо потрібно) паспортних та біографічних даних в реєстраційних бланках.

V. Фіксування відповідей обстежуваного на запитання особистісного опитувальника або самостійне занесення обстежуваним відповідей у реєстраційні бланки.

VI. Оброблення результатів тесту відповідно до вимог рекомендацій.

Для ефективності психодіагностичне дослідження, проводять так, щоб не дати зрозуміти обстежуваним, яка риса особистості вивчається і як будуть інтерпретуватися результати, інакше відповіді будуть відображати їхню власну точку зору, а не реальне положення справ (уявлення окремих обстежуваних про свою особистість можуть бути суттєво перекрученими) [1, 15].

Для проведення якісного дослідження необхідно дотримуватися загальних принципів психодіагностики: прогностична цінність, 
валідність, надійність, точність, практичність $[1,4,6,7,8,10,13,15]$.

Дослідження грунтується на давно відомих нам методах, таких як: спостереження, анкетування, психодіагностика та експеримент, що дає первинний емпіричний матеріал для аналізу, узагальнення, осмислення в контексті єдиного методу $[6,7,8]$.

Як зазначає Л. Карамушка, дослідження іміджу організації здійснюється $з$ урахуванням психодіагностичних особливостей таких, як: характеристика персоналу, зовнішні атрибути, характеристика особистості керівника та його команди, якість діяльності, piвень комфортності діяльності, ціна послуг [4].

У відповідності до мети і завдань, дослідження виконувалося у три етапи.

На першому етапі проведено теоретичний аналіз сучасних тенденцій щодо дослідження створення іміджу вищих навчальних закладів країни. Досліджено наукові підходи вітчизняних та зарубіжних науковців щодо вивчення основних категорій, понять та змісту формування іміджу організацій. Підібрано та обгрунтовано психодіагностичний інструментарій дослідження компонентів іміджу. Визначено концептуальну модель дослідження.

На другому етапі проведено емпіричне дослідження. 3'ясовано зміст, структуру іміджу вищого навчального закладу, визначено структурні компоненти, проаналізовано взаємозв'язки детермінант і компонентів іміджу вищого навчального закладу, розроблено програму психологічної діагностики іміджу вищого навчального закладу.

На третьому етапі проведено формуючий експеримент. Здійснено порівняльний аналіз результатів апробації програми психологічної діагностики іміджу вищого навчального закладу і сформовано висновки $[4,7]$.

Під час проведенні психодіагностичної роботи враховано ряд вимог, які зумовили вибір необхідних методик для об'єктивного вивчення предмета нашого дослідження. У дослідженні увага приділяється аналізу тих аспектів проблем, які відображають особливості психологічної діагностики компонентів іміджу освітньої установи, що вимагає створення відповідного комплексу тестів $[4,5,6$, 7].

Обов'язковою умовою успішного проведення психодіагностичної роботи є обгрунтування підбору адекватних методик, які відображають предмет нашого дослідження. Найбільш доцільним під час дослідження психологічних компонентів іміджу університету вважається інтегративний підхід, який базується на такій характеристиці особистості, як цілісність. Не менш важливий критерій відбору методик - їх інформативність $[4,6,7,8]$.

В науці існують певні загальноприйняті принципи, якими треба оперувати, проводячи психологічне дослідження. Основними принципами, яких ми дотримувались під час дослідження були такі: 
- $\quad$ принцип розвитку - поняття іміджу університету вивчається в безперервному розвитку - дослідження іміджу проводились і раніше як вітчизняними, так і зарубіжними науковцями, в наш час вивченню іміджу приділяється теж не мало уваги, і це сприяло подальшому вивченні цього феномену;

- $\quad$ принцип системності - досліджуючи поняття іміджу ми зважали на його взаємозв'язок з іншими проявами, а зокрема 3 поняттям індивідуального іміджу керівника, культурою організації. В роботах науковців зазначається взаємозв'язок іміджу керівника $з$ іміджем всієї організації. Індивідуальний імідж керівника $є$ одним 3 важливих чинників, які також впливають на формування організаційного іміджу. Також не мало уваги приділяється і організаційній культурі, яка входить до показників формування іміджу. Отже, імідж пов'язаний з безліччю компонентів, має достатньо проявів, які досліджуються в системності при вивчення іміджу організації;

- $\quad$ принцип детермінізму (причинної обумовленості): для вивчення даного явища виявлені причини, які його викликають i породжують дослідження цього феномену. А особливо, у сучасних умовах розвитку ринку в Україні все більшої актуальності набуває проблема створення та підтримки реального позитивного імі- джу освітніх установ, що дозволяє забезпечити стійкі конкурентні переваги, залучити до співпраці нових потенційних партнерів, вигравати різні освітянські гранти, брати участь в програмах обміну студентів $[6,7]$.

Для досягнення поставленої мети і визначених завдань використано як загальнонаукові, так і спеціальні методи дослідження: теоретичного характеру: аналіз наукової літератури, узагальнення отриманої інформації, системний аналіз та інтерпретація даних; емпіричного характеру: спостереження, бесіда (для отримання соціально-психологічної інформації та психодіагностичних висновків керівного складу, науково-педагогічних працівників та обслуговуючого персоналу університету) [1, 7, $15]$.

Вся концепція роботи побудована на дослідженні 6 рівнів компонентів іміджу вищого навчального закладу.

В основу емпіричного дослідження покладено наступні методики: для дослідження індивідуально-психологічного рівня - 16факторний особистісний опитувальник Р. Кеттелла (В. Бодров) та Фрайбургський особистісний опитувальник FPI ( у модифікації А. Крилова) [1, 7] 16-факторний особистісний опитувальник Р. Кеттелла дозволяє з'ясувати особливості характеру, схильностей та інтересів особистості. Даний опитувальник Р. Кеттелла одна 3 найбільш відомих багатофакторних методик, створена в рамках об'єктивного 
експериментального підходу до дослідження особистості. Фрайбургський багатофакторний особистісний опитувальник FPI призначений для діагностики станів і властивостей особистості, які мають першорядне значення для процесу соціальної адаптації та регуляції поведінки.

Для дослідження мотиваційного рівня - «Тест загальних здібностей до підприємницької діяльності» Ю. Пачковського; Методика на визначення мотивів професійної діяльності (Л. Карамушка).

Для визначення соціального рівня - Діагностика соціально-психологічного клімату колективу (О. Михалюк, А. Шалито); Методика визначення рівня соціальної фрустрації; Оцінка рівня задоволеності якості життям; Методика «Вільних асоціацій» (В. Бодров), яку використовували для визначення критеріїв дослідження проблеми іміджу.

Для дослідження комунікативного рівня - методика Т.Лірі (В. Бодров) 3 метою визначення уявлення особистості про себе, ставлення до людей за самооцінкою.

Для дослідження професійного рівня методика «Керівник очима підлеглих»; методика «Стиль керівництва» (В.Захарова, А.Журавльова); анкета «Викладач очима студентів»; методика Дж. Холланда (А. Крилов, С. Манічев), завдяки якій визначено рівень взаємозв'язків типу особистості зі сферою професійної діяльності.

Для дослідження типологічного рів- ня - Опитувальник структури темпераменту В.М. Русалов (ОСТ); методика А.Звєркової, Е. Ейдмана на визначення рівня емоційновольової регуляції $[1,4,6,7,15]$.

До статистичного оброблення емпіричних даних віднесено: обчислення первинних описових статистик; кореляційний аналіз (для встановлення кількісних залежностей між досліджуваними особливостями), факторний аналіз, моделювання [1].

Психологічний інструментарій дослідження компонентів іміджу університету має комплексне та системне призначення, що дає можливість з'ясувати особливості обстежуваних на психологічному, мотиваційному, соціальному, комунікативному, професійному та типологічному рівнях.

Відповідно до мети і завдань розроблено концептуальну модель дослідження, яка включає теоретичні засади дослідження компонентів іміджу, обгрунтування методів та методик, особливості організації роботи.

Отже, враховуючи різноманіття методичних підходів і принципів дослідження особистості під час дослідження компонентів іміджу до мети і завдань застосовано генетикомоделюючий метод (ГММ) дослідження особистості, в основу якого покладено систему таких п'яти принципів, як: аналіз результатів за «одиницями», єдності організаційної креативності, рефлексивного релятивізму, єдності генетичної і соціальної ліній розвитку, який запропонував С. Максименко (2012), що, на 
наш погляд, нині є інтегруючим системнофункціональним методом дослідження особистості [10].

Висновки. На підставі аналізу наукових джерел визначено психодіагностичний інструментарій дослідження психологічних компонентів, що впливають на формування іміджу вищого навчального закладу. При цьому ми розглянули загальнонаукові принципи дослідження: принцип детермінізму та розвитку, єдності свідомості та діяльності, принцип системного підходу розуміння особистості; принцип психологічної теорії діяльності; методологічні принципи організації дослідження.

Окрім того, застосовано психомоделюючий метод дослідження в основу якого покладено систему таких п'яти принципів, як: аналіз результатів за «одиницями», єдності організаційної креативності, рефлексивного релятивізму, єдності генетичної і соціальної ліній розвитку, який запропонував С. Максименко (2012), що, на наш погляд, нині $€$ інтегруючим системно-функціональним методом дослідження особистості.

Психологічний інструментарій дослідження психологічних компонентів іміджу вищого навчального закладу має системне призначення, що дав можливість 3'ясувати особливості обстежуваних на індивідуальнопсихологічному, мотиваційному, соціальному, комунікативному, професійному, типологічному рівнях.

Розроблено і розкрито зміст концептуа- льної моделі дослідження детермінант іміджу вищого навчального закладу з включенням таких блоків, як : теоретико-методологічне підгрунтя дослідження іміджу, етапи дослідження, психодіагностичний блок методик та компоненти формування іміджу вищого навчального закладу.

\section{Перспектива подальшого досліджен-} ня - полягає у апробації психодіагностичного інструментарію, спрямованого на визначення психологічних детермінант іміджу вищого навчального закладу і обгрунтуванні практичних рекомендацій щодо психологічної діагностики іміджу вищого навчального закладу.

\section{Перелік використаних джерел:}

1. Бурлачук Л. Ф. Психодиагностика: Учебник для вузов. - СПб.: Питер, 2006. - 351 с.

2. Беккер Е., Бурделова Т., Юданова А. Бренд и экономическая устойчивость вуза. - М.: КноРус, 2012. $560 \mathrm{c}$

3. Даниленко Л. В. "Все про імідж: відпідходів до рекомендацій”, журнал "Маркетинг i маркетингові дослідження" № 04. - 2007. - 250 с.

4. Карамушка Л. М. Психологічні детермінанти розвитку організаційної культури: Монографія / Л.М. Карамушка, О.В. Креденцер, К.В. Терещенко [та ін.] ; за ред. Л.М. Карамушки. - К.: Педагогічна думка, 2015. $288 \mathrm{c}$.

5. Карамушка Л. М. Створення іміджу навчального закладу як важливий напрямок менеджменту освіти / Л.М. Карамушка // Управління сучасними навчальновиховними закладами в системі освіти : Матеріали міжрег. наук.- практ. конф.- Запоріжжя, 1996. - 140 с.

6. Карамушка Л. М., Сняданко І.І. Психологія організаційної культури: Навчальний посібник. - К. - Львів: 
Край, 2010. - 212 с.

7. Корольчук М. С. Психодіагностика. / М. С. Корольчук, В. І. Осьодло. Навч. посібник. - К. : Ніка-Центр, 2014. - $400 \mathrm{c}$.

8. Корольчук M. С. Психологія реклами: навч. посіб. для студ. вищ. навч. закл. / О.В.Зазимко, М.С. Корольчук, В.М. Корольчук та ін. - Київ: нац. торг.- екон. унT, 2016. - 384c.

9. Кубко В. П. Передумови та особливості формування моделі іміджу вищого навчального закладу / В. П. Кубко // Гілея: науковий вісник. - 2015. - Вип. 103. - 283$286 \mathrm{c}$.

10. Максименко С. Д. Підприємництво: психологічні, організаційні та економічні аспекти: навч. посібник / С. Д. Максименко, А. А. Мазаракі, Л. П. Кулаковська , Т. Ю. Кулаковський. - К. : КНТЕУ, 2012. $-720 \mathrm{c}$.

11. Маценко В. Технологія іміджу / В. Маценко.-К. : Главник, 2005. - 96 с.

12. Панасюк А. Ю. Я - имиджмейкер. А. Ю. Панасюк. - М. : Дело, 2003. - 470c.

13. Психолого-педагогічні особливості розвитку особистості в освітньому просторі: збірник тез доповідей Всеукраїнської науково-практичної конференції, 17-18 травня 2017 р., Мукачево /Ред.кол.:Т.Д. Щербан (гол.ред) та ін. - Мукачево: Вид-во МДУ, 2017. - 250 с. 14. Перелигіна О. Б., Психологія іміджу. - М.: АспектПрес, 2002. - 360 c.

15. Райгородский Д. Я. Практическая психодиагностика. Методики и тесты. - Самара: Издательский Дом «БАХРАМ-М», 2001. -672 c.

16. Про Національну стратегію розвитку освіти в Україні на період до 2021 року Президент України; Указ, Стратегія від 25.06.2013 № 344/2013.

\section{References (Transliteration):}

1. Burlachuk L. F. Psychodiagnostics: Textbook for high schools. - St. Petersburg: Peter, 2006. - 351 p.

2. Becker E., Burdelova T., Yudanova A. Brand and eco- nomic stability of the high school. - M .: KnoRus, 2012. $560 \mathrm{~s}$

3. Danilenko L. $V$. "Everything about image: from approaches to recommendations", magazine "Marketing and marketing research" number 04. - 2007. - $250 \mathrm{~s}$.

4. Karamushka L. M. Psychological determinants of organizational culture development: Monograph / L. M. Karamushka, O.V. Kredentser, K.V. Tereshchenko [and others]; Ed. LM Karamushki - K .: Pedagogical thought, 2015. 288 pp.

5. Karamushka L. M. Creating an image of an educational institution as an important direction of education management / L.M. Karamushka // Management of Modern Educational Institutions in the System of Education: Interregional Materials. Sciences - practice Conf. - Zaporozhye, 1996. $140 \mathrm{c}$.

6. Karamushka L. M., Snyadanko I.I. Psychology of Organizational Culture: Textbook. - K. - Lviv: Krai, 2010. - 212 p.

7. Korolchuk M. S. Psychodiagnostics. / M. S. Korolchuk, V. I. Osiodlo. Teaching manual. - K.: Nika-Center, 2014. $400 \mathrm{~s}$.

8. Korolchuk M. S. Psychology of advertising: Teach. Manual For the stud Higher Teach Shut down / O.V. Zazimko, MS Korolchuk, V.M. Korolchuk et al. - Kyiv: National Trade.- econ. Un-t, 2016. - 384 pp.

9. Kubko V. P. Prerequisites and Peculiarities of Modeling the Image of a Higher Educational Institution / V.P.Kubko / / Gilea: Scientific Bulletin. - 2015. - Issue 103. - 283-286 p.

10. Maksimenko S. D. Entrepreneurship: psychological, organizational and economic aspects: teaching. Manual / S. D. Maksimenko, A. Mazaraki, L. P. Kulakovskaya, T. Yu. Kulakovsky. - K.: KNTEU, 2012. - 720 p.

11. Matsenko V. Technology of image / V. Matsenko. - K.: Chief, 2005 - $96 \mathrm{p}$.

12. Panasyuk A. Yu. I am an image maker. A. Yu Panasyuk. - M.: Case, 2003. - 470s.

13. Psychological and pedagogical peculiarities of personality development in the educational space: a collection of 
abstracts of the All-Ukrainian scientific-practical conference, May 17-18, 2017, Mukachevo / Ed. Col.: T.D. Scherban (Goal.red) and others. - Mukachevo: MSU, 2017. $-250 \mathrm{~s}$.

14. Periligina O. B., Psychology of the image. - M .: Aspect-Press, 2002. - $360 \mathrm{p}$.

15. Raygorodsky D. Ya. Practical psychodiagnostics. Methods and tests. Tutorial. - Samara: Publishing House "BAKHRAM-M", 2001. - 672 p.

16. About the National Strategy for the Development of Education in Ukraine until 2021President of Ukraine; Decree, Strategy dated June 25, 2013 № 344/2013.

\section{Chernega Natalia}

Ph.D. student in psychological department at Kyiv National Trade and Economic University, Kyiv (Ukraine)

\section{ORGANIZATION OF WORK AND CONCEPTUAL MODEL OF THE STUDY OF PSYCHOLOGICAL COMPONENTS OF UNIVERSITY IMAGE}

\section{ABSTRACT}

In the article «Organization of the conceptual model and research the psychological components of the image of the University» an analysis of scientific approaches, organization of work, research tools psychodiagnostic defined components that affect the formation of the image of the university, defining the content of the conceptual model, grounded methods. This study uses general scientific principles: the principle of system approach to understanding personality principle of determinism and development, unity and consciousness of the individual, methodological principles of research.

The analysis of scientific sources theoretical and methodological approaches of psycholog- ical determinants of image formation educational institutions found that a significant number of identifiable components indicate the possibility and the need to clarify the internal and external factors that contribute to image formation, and on the other side - indicate need for an integrated approach to research on determinants psychodiagnostic image of higher education.

Problems related to psychological diagnosis image of higher education organization in modern Ukrainian and foreign scientific literature considered insufficiently because scientific research is a practical objective study methods and develop a conceptual model study forming the image of the university.

Therefore, the analysis of scientific sources of theoretical and methodological approaches developed and the content model research component image of the institution of higher education to include such units as the theoretical and methodological basis of research image stages of research psychodiagnostic block techniques and components forming the image of higher education institution.

Key words: conceptual model, research, psychodiagnostic, image, components, higher educational institution. 


\section{Чернега Наталья}

Аспирант кафедры психологии Киевского национального торгово-экономического университета, м. Киев (Украина)

\section{ОРГАНИЗАЦИЯ РАБОТЫ И КОНЦЕПТУАЛЬНАЯ МОДЕЛЬ ИССЛЕДОВАНИЯ ПСИХОЛОГИЧЕ- СКИХ КОМПОНЕНТОВ ИМИДЖА УНИВЕРСИТЕТА}

Аннотация. В статье «Организация работы и концептуальная модель исследования психологических компонентов имиджа университета» представлен анализ научных подходов, организацию работы, определены психодиагностические инструментарий исследования компонентов, влияющих на формирование имиджа высшего учебного заведения, определено содержание концептуальной модели, обоснованы методы исследования. При этом использованы общенаучные принципы исследования: принцип системного подхода понимания личности, принцип детерминизма и развития, единства сознания и деятельности личности, методологические принципы организации исследования.

По результатам анализа научных источников теоретико-методологических подходов исследования психологических детерминант формирования имиджа образовательных учреждений установлено, что значительное количество определенных компонентов свидетельствуют о возможности и необходимости выяснения внутренних и внешних факторов, обусловливающих формирование имиджа, а с другой стороны - указывают на необходи- мость комплексного подхода в исследовании по психодиагностики детерминант имиджа высшего учебного заведения.

Проблемы, связанные с психологической диагностикой имиджа высшей образовательной организации, в современной украинской и зарубежной научной литературе рассматриваются недостаточно полно, поэтому научной практической задачей исследования является обоснование методов и разработки концептуальной модели исследования формирования имиджа университета.

Итак, по результатам анализа научных источников теоретико-методологических подходов, разработано и раскрыто содержание модели исследования компонентов имиджа высшего учебного заведения с включением таких блоков, как: теоретикометодологическое основание исследования имиджа, этапы исследования, психодиагностический блок методик и компоненты формирования имиджа высшего учебного заведения.

Ключевые слова: концептуальная модель, исследования, психодиагностика, имидж, компоненты, высшее учебное заведение.

Дата отримання статті: 15.06.2017 Дата рекомендації до друку: 03.07.2017 